\title{
Meta-Analysis of Scientific Papers in the Field of Sports Training Published in the Journal Sport Mont in 2016
}

\author{
Marina Vukotic \\ University of Montenegro, Faculty for Sport and Physical Education, Niksic, Montenegro
}

\begin{abstract}
A B S T R A C T
The main goal of this research was to determine one meta analysis of published original scientific papers in the field of sports training in Sport Mont in 2016. From the review of the published original scientific papers that are being analyzed, it can be seen that this is a longitudinal research. In this paper, a meta analysis of 6 papers in the field of sports training was conducted. Analyzing the basic central and dispersion parameters in all original scientific papers in the final state, it was noticeable that the arithmetic meanings had better values in almost all values compared to the initial state. For the determination of statistical significance, the differences in arithmetic meanings (partial quantitative changes) of the variables for evaluating different tests in published works, the t-test for dependent samples and the multivariate analysis of ANOVA and MANOVA were applied. T-test values and multivariate analysis were at significance or significance level (Sig.) Of 0.01 ( $p \leq .01$ ) in all variables. This systematic overview shows a comparative analysis of the collected studies and the processed data. It can be concluded that the training program of all scientific orginal papers has led to positive transformations.
\end{abstract}

Key words: Meta-Analysis, Sport Mont, Sports Training

\section{Uvod}

Sport Mont je časopis koji se sastoji od originalnih recenziranih naučnih članaka i interdisciplinarnih prikaza istraživanja iz oblasti sportske nauke, čiji su autori naučnici iz cijelog svijeta. Početak izlaženja publikacije bio je za uredništvo veoma težak, ali iz godine u godinu situacija se mijenjala, radovi koji su objavljeni bili su sve kvalitetniji, pa se može reći da je časopis "Sport Mont" dospio do visokog nivoa u svijetu nauke. Svrha časopisa je promocija nauke $\mathrm{i}$ istraživanja, sa posebnom pažnjom posvećenom sportskoj nauci širom Crne Gore i izvan nje. Ova meta-analiza daje pregled objavljenih orginalnih naučnih radova iz oblasti sportskog treninga u časopisu "Sport Mont" u 2016. godini.

Sportski trening je kompleksan pedagoški proces, koji se konkretizuje u organizovanom vježbanju-radu, koje se ponavlja sa takvim opterećenjem da aktivira fiziološke procese superkompezacije i adaptacije organizma. Time se postiže poboljšanje fizičkih, psihičkih, intelektualnih, tehničkih i taktičkih kvaliteta sportsite, koji se manifestuju u postizanju takmičarskih rezultata (Bjelica, 2011). U svrhu optimizacije treninga, važno je imati uvid u aktuelno stanje relevantnih sposobnosti, osobina $\mathrm{i}$ znanja sportista, kao i uvid u specifične zahtjeve pojedinog sporta ili sportske discipline. Neophodno je pratiti i utvrditi one motoričke i funkcionalne pokazatelje koji će pomoći u dijagnostici stanja treniranosti i omogućiti programiranje i kontrolu treninga sa adekvatnim opterećenjima, sredstvima i metodama (Vukotic, 2010). Mnoge naučne discipline su u tijesnoj vezi sa sportskim treningom, te u svojim definicijama sportskog treninga navode njegovu veliku složenost koja se ogleda u multidisciplinarnoj međuzavisnosti i interakcijskim odnosima velikog broja kriterijuma, koje za sad nije moguće registrovati u obliku celokupnog-integralnog jedinstvenog fenomena.

Osnovni cilj ovog istraživanja je bio da se provede meta- analiza objavljenih originalnih naučnih radova iz oblasti sportskog treninga u časopisu "Sport Mont" 2016.godine.

\section{Metod}

Meta-analiza u ovom radu je sprovedena na objavljenim originalnim naučnim radovima iz oblasti sportskog treninga u časpisu "Sport Mont" 2016. Iz pregleda svih objavljenih originalnih naučnih radova koje analiziramo, vidi se da je riječ o longitudalnim istraživanjima, sa ciljem da se u vremenski dvije različite tačke utvrde promjene kod različitih sposobnosti ispitanika, pod uticajem programiranog trenažnog rada. U pomenutom časopisu je objavljeno 30 naučnih radova iz različitih multidisciplinarnih i monodisciplinarnih oblasti. U ovom radu je sprovedena metaanaliza 6 radova iz oblasti sportskog treninga. Skoro svi radovi su obuhvatali antropomotoriku. Bazične motoričke sposobnosti su sposobnosti koje ljudi već posjeduju, a specifične sposobnosti su stvorene i razvijene u specifičnim uslovima, što je najevidentnije kod sportista (Bjelica, Popović i Gardasevic, 2016b).

Program obuke obuhvatao je četrdeset četiri jedinice na uzorku od 120 fudbalera na kadetskom nivou, a za procjenu ispitanika su korišćena tri testa: taping nogom o zid, sprint na 20 $\mathrm{m}$ iz visokog starta i sprint $60 \mathrm{~m}$ visokog starta (Gardasevic, Bjelica i Vasiljevic, 2016). Program obuke obuhvatao je četrdeset četiri jedinice na uzorku od 120 fudbalera na kadetskom nivou, a za procjenu ispitanika su korišćena tri testa:

ležanje-sjed za 30 sekundi; sklekovi; zakloni u ležanju-ispravljanje trupa (Gardasevic, Bjelica, Vasiljević i Milasinovic, 2016). Program obuke je trajao deset nedelja, za procjenu kontrolne i eksperimentalne grupe na uzorku kod 59 žena (Andrasic, Ujsasi, Cvetkovic, Orlic i Milic, 2016). Na uzorku od 130 odbojkašica izvršen je nivo poboljšanja motoričkih vještina pod uticajem kinezioloških operatora u periodu od 6 mjeseci, 
varijable su podijeljene u dvije grupe: devet varijabli za procjenu osnovnih motoričkih vještina i pet varijabli za procjenu situaciono motoričkih vještina (Mahmutovic, Radjo, Talovic, Lakota, Alic, Jeleskovic, 2016). Upoređivanje i preispitivanje efekata dodatnog programa treninga snage izvršeno je nakon osam nedelja na uzorku kod 18 fudbalera (Radjo, Alic, Bajramovic, Jeleskovic, Covic, Likic i Mekic, 2016). Na uzorku od 12 džudista i 12 učenika utvrđeni su efekti dva različita protokola za oporavak na srčanu frekvenciju tokom prvog minuta oporavka (Vujkov, Casals, Krneta i Drid, 20016).

U ovim objavljenim originalnim naučnim radovima, u segmentu komparativne statistike, za utvrđivanja razlika primijenjenih varijabli na inicijalnom i finalnom stanju i na kontrolnim i eksperimentalnim grupama trenažnog programa, korišćena je diskriminativna parametrijska procedura Studentov T-test za zavisne uzorke i multivarijantna analiza MANOVA i ANOVA.

\section{Rezultati}

U svim pomenutim originalnim naučnim radovima su analizirani prvo osnovni dekriptivni statistički parametri svih va- rijabli za procjenu testova u inicijalnom i finalnom mjerenju i eksperimentalne i kontrolnoj grupi. Analizirajući osnovne centralne i disperzione parametre kod svih originalnih naučnih radova u finalnom stanju, uočljivo je bilo da su aritmetičke sredine kod gotovo svih vrijednosti imale bolje vrijednosti u odnosu na inicijalno stanje. Za utvrđivanje statističke značajnosti (signifikantnosti) razlika aritmetičkih sredina (parcijalne kvantitativne promjene) varijabli za procjenu različitih testova u objavljenim radovima, primijenjen je T-test za zavisne uzorke i multivarijantna analiza ANOVA i MANOVA. Vrijednosti T-testa i multivarijantna analiza su bile na nivou značajnosti ili signifikantnosti (Sig.) od $0.01(\mathrm{p} \leq .01)$ u svim varijablama. Svi objavljeni originalni naučni radovi su pokazali da postoje statistički značajne razlike kod gotovo svih varijabli, te se stoga može reći da je došlo do pozitivnih statistički značajnih parcijalnih efekata trenažnog programa, a vrijednosti T-testa i mulivarijantne analize ANOVA i MANOVA bile su značajne na nivou pouzdanosti $\mathrm{p}<.01$ kod svih varijabli za procjenu različitih testova. Važno je naglasiti da komparativne studije omogućuju identifikaciju, opis i upoređivanje strukture, u ovom slučaju sportskog treninga, koja se temelji na preciznim metodama.

Tabela 1. Studije koje su analizirale objavljene orginalne radove iz oblasti sportskog treninga

\begin{tabular}{|c|c|c|c|c|}
\hline Autor & $\begin{array}{c}\text { Cilj } \\
\text { istraživanja }\end{array}$ & $\begin{array}{c}\text { Uzorak/ } \\
\text { varijable }\end{array}$ & $\begin{array}{l}\text { Statist. } \\
\text { Analiza }\end{array}$ & Rezultati \\
\hline $\begin{array}{l}\text { Gardašević i } \\
\text { sar. (2016) }\end{array}$ & $\begin{array}{l}\text { Efekti pripremnog } \\
\text { perioda na repetitiv- } \\
\text { nu snagu }\end{array}$ & $\begin{array}{l}120 \text { fudbalera kadetskog uzrasta / } \\
\text { ležanje-sjed za } 30 \text { sekundi; skle- } \\
\text { kovi; zakloni u ležanju-ispravlja- } \\
\text { nje trupa }\end{array}$ & T-test & $\begin{array}{l}\text { utvrđene su statistički značajne } \\
\text { razlike u svim parovima varija- } \\
\text { bli između inicijalnog i final- } \\
\text { nog stanja, na nivou } \\
\text { p }<.01\end{array}$ \\
\hline $\begin{array}{l}\text { Gardašević i } \\
\text { sar. (2016) }\end{array}$ & $\begin{array}{l}\text { Efekti pripremnog } \\
\text { perioda na brzinu } \\
\text { pokreta }\end{array}$ & $\begin{array}{l}120 \text { fudbalera kadetskog uzrasta / } \\
\text { taping nogom o zid; sprint na } 20 \mathrm{~m} \\
\text { visoki start; sprint na } 60 \mathrm{~m} \text { visoki } \\
\text { start }\end{array}$ & T-test & $\begin{array}{l}\text { utvrđene su statistički značajne } \\
\text { razlike u svim parovima varija- } \\
\text { bli između inicijalnog i final- } \\
\text { nog stanja, na nivou } \\
\mathrm{p}<.01\end{array}$ \\
\hline $\begin{array}{l}\text { Andrašić i sar. } \\
\text { (2016) }\end{array}$ & $\begin{array}{l}\text { Efekti grupnog fit- } \\
\text { ness programa ve- } \\
\text { žbanja kod dinamič- } \\
\text { koj snage }\end{array}$ & $\begin{array}{l}59 \text { žena ( } 20 \text { ekspirimentalna i } 30 \\
\text { konrolna grupa) / ležanje-sjed za } \\
30 \text { sekundi; sklekovi; zakloni u } \\
\text { ležanju-ispravljanje trupa za } 30 \mathrm{~s} \text {, } \\
\text { skokovi } 30 \mathrm{~s} \text {. }\end{array}$ & MANOVA & $\begin{array}{l}\text { utvrđene su statistički značajne } \\
\text { razlike u svim parovima varija- } \\
\text { bli između eksperimentalne i } \\
\text { kontrolne grupe, na nivou } \\
\text { p }<.01\end{array}$ \\
\hline $\begin{array}{l}\text { Mahmutović i } \\
\text { sar. (2016) }\end{array}$ & $\begin{array}{l}\text { Nivo poboljšanja } \\
\text { motoričkih odbojka- } \\
\text { šica pod uticajem } \\
\text { kinezioloških opera- } \\
\text { tora }\end{array}$ & $\begin{array}{l}130 \text { odbojkašica / } 9 \text { varijabli } \\
\text { motoričkih vještina i } 5 \text { situacionih } \\
\text { motornih vještina }\end{array}$ & T-test & $\begin{array}{l}\text { Utvrđene su značajne statistič- } \\
\text { ke razlike odabranoj diskrimi- } \\
\text { natorrnoj funkciji osnovnih } \\
\text { motoričkih vještina inicijalnog } \\
\text { i finalnog stanja, na nivou } \\
\text { p }<.01\end{array}$ \\
\hline $\begin{array}{l}\text { Rađo i sar. } \\
(2016)\end{array}$ & $\begin{array}{l}\text { Efekti dodatnog } \\
\text { programa treninga } \\
\text { kod fudbalara nakon } \\
\text { osme nedelje pripe- } \\
\text { me }\end{array}$ & $\begin{array}{l}18 \text { fudbalra / izokinetički dinamo- } \\
\text { metar Biodek }\end{array}$ & T-test & $\begin{array}{l}\text { Utvrđene su značajne statistič- } \\
\text { ke razlike u oba kraka za mak- } \\
\text { simalnu izlaznu snagu i pro- } \\
\text { sječno radon opterećenje u } \\
\text { fleksiji i proširenju, } \\
\text { na nivou } \\
\text { p }<.01\end{array}$ \\
\hline $\begin{array}{l}\text { Vujkov i sar. } \\
\text { (2016) }\end{array}$ & $\begin{array}{l}\text { Utvrditi efekte dva } \\
\text { različita protokola } \\
\text { za oporavak }\end{array}$ & $\begin{array}{l}\text { 12džudista i } 12 \text { članova kontrolne } \\
\text { grupe / test trajnog trenja za sni- } \\
\text { manje HR (bpm) }\end{array}$ & ANOVA & $\begin{array}{l}\text { Utvrđene su značajne statistič- } \\
\text { ke razlike između primijenjenih } \\
\text { protokola u svim nivoima za } \\
\text { obje grupe, na nivou } \\
\mathrm{p}<.01\end{array}$ \\
\hline
\end{tabular}

\section{Diskusija}

U ovom radu je izvršena meta-analiza objavljenih originalnih naučnih radova iz oblasti sportskog treninga. Iz pregleda svih objavljenih orginalnih naučnih radova koji su analizirani, vidi se da je riječ o longitudalnim istraživanjima, sa ciljem da se u vremenski dvije različite tačke utvrde promjene kod različitih varijabli, pod uticajem programiranog trenažnog rada. Statistički značajne promjene su uočene kod svih varijabli za procjenu brzine kretanja kod fudbalera. Ovo je potvrdilo hipotezu da očekivane značajne 
pozitivne kvantitativne promjene osnovnih motoričkih sposobnosti utiču na predloženi model obuke u pripremnom periodu (Gardasevic, Bjelica i Vasiljevic, 2016). Statistički značajne promjene su uočene kod svih varijabli za procjenu repetitivne snage kod fudbalera. Potvrđena je hipoteza da su očekivane kvantitativne promjene osnovnih motoričkih sposobnosti koje utiču na predloženi model obuke u pripremnom periodu sa petnaestogodišnjim fudbalerima (Gardasevic, Bjelica, Vasiljevic i Milasinovic, 2016). Utvrđeno je da su statistički značajne razlike između eksperimentalnih i kontrolnih grupa kod tri od pet varijabli, u korist eksperimentalne grupe kod žena (Andrasic, Ujsasi, Cvetkovic, Orlic i Milic, 2016). Analiza kvantitativnih promjena osnovnih motoričkih vještina pokazuje navažnije projekcije na odabranoj diskriminatornoj funkciji odbojkašica (Mahmutovic, Radjo, Talovic, Lakota, Alic, Jeleskovic, 2016). Statistička značajnost promjene je procijenjena na vrhu obrtnog momenta, dok je statistički značajna promjena zabilježena na oba kraka za maksimalnu snagu i prosječno radno opterećenje u fleksiji fudbalera (Radjo, Alic, Bajramovic, Jeleskovic, Covic, Likic i Mekic, 2016). Rezultati su pokazali značajne razlike između primijenjenih protokola u svim nivoima za obije grupe džudista (Vujkov, Casals, Krneta i Drid, 20016).

\section{R E F E R E N C E S}

Andrašić, S., Ujsasi, D., Cvetković, M., Orlić, D., \& Milić, Z. (2016). Impact of recreational fitness training program on dynamic strength of women. Sport Mont, 14(2), 25-29.

Bjelica, D. (2010). Istraživačke metode u sportskom treningu. Sport Mont, VII(21-22), 154-163.

Bjelica, D., Popović, S., i Gardašević, J. (2016b). Opći principi planiranja i programiranja fizičkih priprema sportaša. Zbornik radova 14.godišnje međunarodne konferencije "Kondicijska priprema sportaša” (190-192), Zagreb: Udruga kondicijskih trenera Hrvatske.

Gardasevic, J., Bjelica, D., \& Vasiljevic, I. (2016). Six-week preparation period and its effects on transformation movement speed with football players under 16. Sport Mont, 14(1), 13-16.

Gardasevic, J., Bjelica, D., Vasiljevic, I., \& Milasinovic, R. (2016). The effects of the training in the preparation period on the repetitive strength transformation with cadet level
Da podsjetimo, časopis “Sport Mont” se sastoji od originalnih recenziranih naučnih članaka i interdisciplinarnih prikaza istraživanja iz oblasti sportske nauke. Svrha časopisa je promocija nauke i istraživanja, sa posebnom pažnjom posvećenom sportskoj nauci širom Crne Gore i izvan nje. Meta-analiza daje pregled objavljenih originalnih naučnih radova iz oblasti sportskog treninga u časopisu "Sport Mont" u 2016. godini. Sistematski pregled pokazuje komparativnu analizu prikupljenih studija i obrađenih podataka. Može se zaključiti da je trenažni program rada kod svih naučnih orginalnih radova iz oblasti sportskog treninga doveo do pozitivnih transformacija. Na osnovu dobijenih rezultata iz originalnih objavljenih naučnih radova može se registrovati određeno stanje sportiste i te rezultate uporediti sa nekim prethodno utvrđenim kriterijumom. Naime, dobijeni rezultati mogu biti usmjereni u pravcu inoviranja planova i programa rada, te prilagođavanju potrebama dotične populacije. Pored dijagnostikovanja, planiranja i programiranja trenažnog procesa, rezultati se mogu primijeniti i u svrhu individualnog praćenja sportista i unošenja korekcije u metode obučavanja, utvrđivanja i unapređivanja razlika sposobnosti kod sportista različitog sporskog usmjerenja. football players. Sport Mont, 14(2), 31-33.

Mahmutović, I., Rađo, I., Talović, M., Lakota, R., Alic, H., \& Jelesković, E. (2016). Level of transformation of motor skills in female volleyball players influenced by training operators. Sport Mont, 14(2), 39-43.

Rađo, I., Alić, H., Bajramović, I., Jelesković, E., Čović, N., Likić, S., \& Mekić, A. (2016). Functional strength training effects on knee flexors and extensors power output in football players. Sport Mont, 14(2), 13-16.

Vujkov, S., Casals, C., Krneta, Z., \& Drid, P. (2016). Ultra short-term heart rate recovery after maximal exercise in two different body positions in elite male judokas compared to students of the sport faculty. Sport Mont, 14(1), 7-11.

Vukotić, M. (2010). Nivo morfoloških karakteristika, motoričkih I funkcionalnih sposobnosti sportista razlicitog sportskog usmjerenja. Neobjavljena magistarska teza. Nikšić: Fakultet za sport i fizičko vaspitanje.

\section{Vukotic}

University of Montenegro, Faculty for Sport and Physical Education, Narodne omladine bb, 81400 Niksic, Montenegro e-mail:marinavukotic@yahoo.com 
